
\title{
触 New Disease Reports \\ First Report of Sclerotium cepivorum causing white rot of garlic in Hungary
}

\author{
J. Bakonyi ${ }^{1 *}$, L. Vajna $^{1}$, A. Szeredi ${ }^{2}$, E. Tímár ${ }^{2}$, G.M. Kovács ${ }^{1,3}$, M. Csősz ${ }^{4}$ and A. Varga ${ }^{5}$ \\ ${ }^{1}$ Plant Protection Institute of the Hungarian Academy of Sciences, Herman O. út 15. H-1022 Budapest, Hungary; ${ }^{2}$ Szeredi \\ Ltd., H-6775 Kiszombor, Hungary; ${ }^{3}$ Eötvös Loránd University, Institute of Biology, Department of Plant Anatomy, Pázmány \\ Péter sétány 1/C. H-1117 Budapest, Hungary; ${ }^{4}$ Cereal Research Non-Profit Ltd. Company, Alsó kikötő sor 9. H-6726, \\ Szeged, Hungary; ${ }^{5}$ Agricultural Office of Csongrád County, Plant Protection and Soil Conservation Directorate, Rárósi út \\ 110. H-6800 Hódmezővásárhely, Hungary
}

*E-mail: jbak@nki.hu

Received: 07 Oct 2010. Published: 12 Jan 2011. Keywords: Allium sativum, Allium cepa, fungal plant disease

Allium species are traditionally important export products of Hungary. In June 2008, premature yellowing and wilting of foliage were observed in a 32 ha commercial garlic field (Allium sativum cv. Arno) within the biggest Allium-producing region of Hungary, $200 \mathrm{~km}$ southeast of Budapest. The underground parts of affected plants were covered with a white mycelial mat producing black spherical sclerotia with diameter up to $0.5 \mathrm{~mm}$ (Fig. 1). Roots and bulbs were rotten and the rot had spread onto the lower part of leaves. Similar symptoms were recorded in the adjacent onion field (Allium cepa cv. Glacier). Finally, the infected plants died. A microscopic examination revealed that sclerotia consisted of a central medulla and a blackish, smooth outer rind (Fig. 2). To isolate the causal agent, several single sclerotia were placed onto potato dextrose agar (PDA) plates and incubated at $20^{\circ} \mathrm{C}$ in the dark. Isolates developed white mycelia and dark sclerotia similar to those observed on naturally infected plants (Fig. 3). In older cultures spermatia-like phialospores (Crowe, 2008) were produced, but sexual structures were absent. The pathological and morphological characteristics suggested that the fungus was Sclerotium cepivorum (Mordue, 1976), the causal agent of white rot of Allium species. One isolate from garlic was deposited in the PPIHAS Mycology Collection (WDCM824) under the accession number H-292. The rDNA ITS sequence (GenBank Accession No. FJ460433) of this isolate showed 99-100\% sequence similarity to GenBank accessions of $S$. cepivorum. The pathogenicity of isolate $\mathrm{H}-292$ was tested by placing five mycelial PDA discs (one $\mathrm{cm}$ diameter) with mature sclerotia one $\mathrm{cm}$ below three cloves of garlic potted in sterile soil. The treatment was repeated three times. Controls received non-inoculated agar discs. Incubation was carried out in a laboratory at room temperature. Within three weeks the emerged plants in infected soil exhibited severe root and bulb rot and died, whereas control plants remained healthy. S. cepivorum was re-isolated from the infected plants.

S. cepivorum is recorded from several countries in Europe, and also from Africa, Asia, Australia and Oceania, as well as North and South America (CMI, 1990). The pathogen can survive in soil and plant residues for years, which is an important consideration for disease management. White rot of garlic and onion was reported to be absent in Hungary (Glits, 1993). This report is the first to prove the occurrence of $S$. cepivorum in this country and is of phytosanitary and economic importance, since the garlic and onion produced in the region where the disease was observed are of premium quality and are a speciality of Hungary.

\section{Acknowledgements}

This work was supported by the Hungarian Scientific Research Fund (OTKA) grants K61107, IN71349 and T 67648.

\section{References}

CMI. 1990. Distribution Maps of Plant Diseases. Map No. 331. Edition 5. Sclerotium cepivorumBerk.

Crowe FJ, 2008. White Rot. In: Schwartz HF, Mohan SK, eds. Compendium of Onion and Garlic Diseases and Pests. St. Paul, MN: The American Phytopathological Society, 22-26.

Glits M, 1993. Hagymafélék betegségei. In: Folk G, Glits M, eds. Kertészeti Növénykórtan. Budapest, Hungary: Mezőgazda Kiadó, 392.

Mordue JEM, 1976. Sclerotium cepivorum. IMI Descriptions of Fungi and Bacteria,No.52, Sheet 512. Kew, Surrey, UK: Commonwealth Mycological Institute.

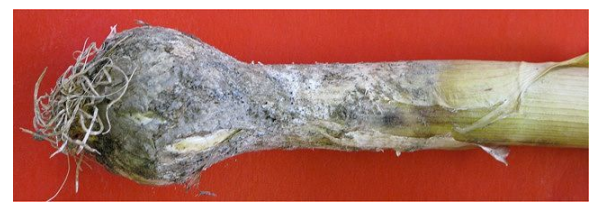

Figure 1
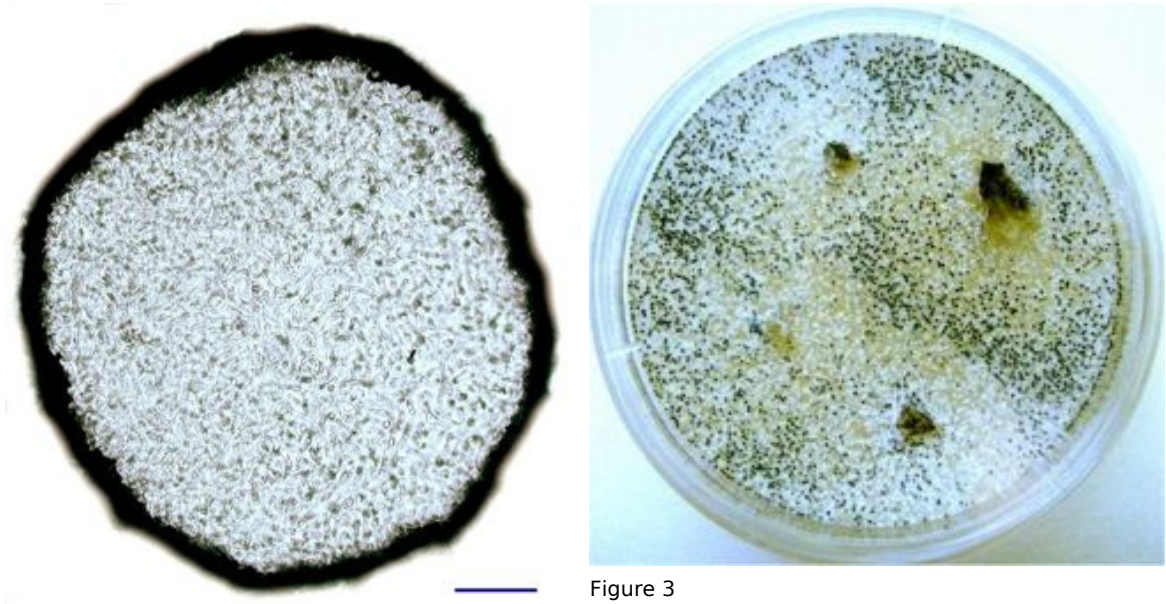

Figure 3

Figure 2

To cite this report: Bakonyi J, Vajna L, Szeredi A, Tímár E, Kovács GM, Csősz M, Varga A, 2011. First Report of Sclerotium cepivorum causing white rot of garlic in Hungary. New Disease Reports 23, 5. [http://dx.doi.org/10.5197/j.2044-0588.2011.023.005]

(c) 2011 The Authors

This report was published on-line at www.ndrs.org.uk where high quality versions of the figures can be found. 